Original Research

\title{
The Correlation between Tri Hita Karana's Implementation and Life Quality of Heart Failure Patients
}

\author{
Ida Ayu Agung Laksmi ${ }^{1 *}$, Putu Wira Kusuma Putra ${ }^{1}$, \& Ayu Made Budihartini ${ }^{1}$ \\ ${ }^{1}$ STIKES Bina Usada Bali, Badung, Indonesia
}

\begin{tabular}{|c|c|}
\hline Article Info & Abstract \\
\hline $\begin{array}{l}\text { Article history: } \\
\text { Received: } \\
30 \text { September } 2020 \\
\text { Accepted: } \\
9 \text { February } 2021\end{array}$ & $\begin{array}{l}\text { Introduction: The quality of life of patients with heart failure is influenced } \\
\text { by several factors, one of which is spiritual factors. Tri Hita Karana (THK) } \\
\text { is one of the concepts of the life order of the Balinese people, which } \\
\text { basically teaches about maintaining harmony between humans and God } \\
\text { (prahyangan), humans and humans (pawongan), humans with the } \\
\text { environment (palemahan). This study aimed to determine the relationship }\end{array}$ \\
\hline $\begin{array}{l}\text { Keywords: } \\
\text { heart failure, quality } \\
\text { of life, Tri Hita } \\
\text { Karana }\end{array}$ & $\begin{array}{l}\text { between THK implementation on the quality of life of heart failure patients } \\
\text { at Regional Hospital of Mangusada. } \\
\text { Methods: A cross-sectional design study was used. In total } 41 \text { heart failure } \\
\text { patients who visited Mangusada Hospital between April to May 2020, } \\
\text { selected using a purposive sampling technique. The research instrument } \\
\text { used was the attitude and behavior implementation of THK and the } \\
\text { Minnesota Living with Heart Failure Questionnaire (MLHFQ). The } \\
\text { Spearman rank test was used in this study. } \\
\text { Results: There were a significant correlation between Tri Hita Karana's } \\
\text { Implementation and Life Quality of Heart Failure Patients in Mangusada } \\
\text { Regional Hospital with p-value (0.001), where }<\alpha(0.05) \text {. } \\
\text { Conclusion: The better the implementation of THK, the better the quality of } \\
\text { life for patients with heart failure. The results of this study were expected } \\
\text { to be used in providing education to patients by implementing THK to } \\
\text { improve the quality of life for patients with heart failure. }\end{array}$ \\
\hline
\end{tabular}

${ }^{*}$ Corresponding Author:

e-mail: agunglaksmi41@gmail.com

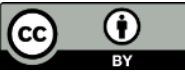

This work is licensed under a Creative Commons Attribution 4.0 International License. 


\section{INTRODUCTION}

Heart failure is a cardiovascular disease that results in high rates of mortality and morbidity [1]. The prevalence of heart disease sufferers in Indonesia according to Basic Health Research data [2] is $1.5 \%$ or an estimated 1,017,290 people, the prevalence of heart disease in Bali is $1.3 \%$ or an estimated 16,481 people. The medical record reports at the Cardiac Polyclinic of RSD Mangusada Badung Regency, the number of heart patients in April 2019 was 1192 cases, and an increase in May 2019 as many as 1223 cases. Preliminary studies that have been carried out, from the medical records at the heart polyclinic of RSD Mangusada, Badung Regency, the incidence of heart failure is ranked $3 r d$ out of 10 cases of heart disease. As of May 2019, there were 106 patients with heart failure.

Heart failure is a chronic disease that can cause a decrease in basic needs and daily activities so that it can affect the patient's quality of life [3]. Heart failure can have an impact on meeting basic needs; changes in body image, lack of self-care, daily activities, sexual dysfunction and worries about the future. Providing repeated care and prolonged treatment for patients with heart failure can cause psychological disorders that trigger negative emotions such as anxiety and psychosocial problems that can hinder the healing process and reduce the quality of life [4]. The quality of life of patients with heart failure is influenced by several factors, namely age, education level, occupation, degree of severity, level of knowledge, depression status, level of anxiety, stress, spirituality, and family support [5].
Bali in the global reform era cannot avoid social conflicts, including patients and families with heart failure. Previous study showed that most of the heart failure patients have sufficient family support $(56,6 \%)$ and only $(18,1 \%)$ have good family support [6]. This shows that the social life of patients and families with heart failure is not harmonious enough. Social disharmony can also be a psychosocial problem that affects the quality of life for heart failure patients.

To overcome psychosocial problems in patients with heart failure can be done by mobilizing coping sources in the form of problem solving skills, social support and beliefs [7]. The Balinese people have the ability to facing that problem with the local wisdom "Tri Hita Karana". Tri Hita Karana is one of the beliefs of the Balinese people, especially those who are Hindu include the concepts of the Balinese way of life that prioritizes the harmony of life so as to create a sense of life comfortably, peacefully, physically and mentally [8].

The Tri Hita Karana philosophy emphasizes that in the process of maintaining health towards a prosperous life, humans are asked to maintain a harmonious relationship between humans and their creators, namely God Almighty (Parhyangan), humans and the environment (Palemahan), and humans and each other (Pawongan). The harmonious relationship can stimulate the release of the hormone of happiness which will activate the body's defense system to an optimal level, so that the body's resistance to various diseases can be increased [9]. This study aims to analyze the correlation between the implementation of Tri Hita Karana and the 
quality of life for heart failure patients at RSD Mangusada.

\section{METHODS}

This research is an observational design with a cross sectional approach. The sampling technique in this study using the NonProbability Sampling technique used was purposive sampling with several inclusion criteria including patients aged $\geq 40$ years, patients with functional classification NYHA class I and II, patients who could read and write while the exclusion criteria were patients with complications. Other diseases that made it impossible to answer the research questionnaire were patients with decreased consciousness or had a stroke. The study was conducted from 25 April to 25 May 2020 at the Cardiac Polyclinic RSD Mangusada. This research has been declared ethical by the Health Research Ethics Commission of Stikes Bina Usada Bali by the ethical acceptance letter no. 040/EA/KEPKBUB-2020.

The population in this study were 106 patients with heart failure at the Polyclinic RSD Mangusada. Sampling in this study is in accordance with Slovin formulation based on the calculation of the number of samples in this study as many as 41 samples. Data was collected through face-to-face interviews to help increase the accuracy of the collected information. The measuring instrument used is the attitude and behavior questionnaire based on Tri Hita Karana which consists of 9 questions about Parhyangan, 5 questions about Pawongan, and 5 questions about Palemahan which are valid $(r>0.3)$ and reliable with alpha cronbach 0.841 .
Quality of life was assessed using the Indonesian version of the Minnesota Living with Heart Failure Questionnaire (MLHFQ) which has been tested for validity $(r>0.3)$ and reliability ( $\alpha$-cronbach of 0.887 ) [10] and has permission to use from Minnesota. The MLHFQ consists of 21 questions consisting of 8 questions on the physical dimension, 5 questions on the emotional dimension and 8 questions on the dimensions of quality of life in general which were developed specifically to evaluate disease progression and care for the quality of life of patients with heart failure. All research data were analyzed using the Spearman Rank statistical test to determine the relationship between the implementation of Tri Hita Karana on the quality of life of patients with heart failure. The hypothesis tests were conducted at a confidence level of $95 \%$ with a $P$-value of 0.05 . If a $P$-value is less than 0.05 , the null hypothesis was rejected.

\section{RESULTS}

Respondents in this study were 41 heart failure patients both male and female who went to the Cardiac Polyclinic RSD Badung Mangusada. Table 1 presents a univariate analysis to determine the characteristics of respondents and table 2 presents a bivariate analysis to analyze the relationship between the two variables using the Spearman Rank non-parametric correlation test.

Table 1 shows that of the 41 total respondents, most of them are male $(56,1 \%)$ and 18 respondents $(43,9 \%)$ are female. Based on job status, only 10 respondents who do not work. Table 1 also shows that most of the respondents (36.6\%) are highly educated. Most of them (85.4\%) have good 
implementation of Tri Hita Karana and (75.6\%) with good quality of life.

Table 2 shows that of the 41 total respondents, 35 respondents who implemented Tri Hita Karana well and of the 35 respondents who implemented Tri Hita Karana well, there were 30 respondents $(73.2 \%)$ who had a good quality of life with $p$ value $0.001(p<0,05)$ which means that there is a relationship between the implementation of Tri Hita Karana and the quality of life for heart failure patients at RSD Mangusada. The correlation coefficient value of 0.610 indicates that the Tri Hita Karana implementation variable and the quality of life have a strong relationship which is positive, indicating that the nature of the relationship between the two variables is unidirectional.

\section{Table 1}

Respondents distribution

\begin{tabular}{ccc}
\hline Distribution & Frequency (n) & Percentage (\%) \\
\hline Gender & 23 & 56,1 \\
Male & 18 & 43,9 \\
Female & & \\
\hline Job Status & 31 & 68.3 \\
\hline Work & 10 & 31,7 \\
\hline Not Working & & \\
\hline Education & 3 & 7,3 \\
\hline No School & 11 & 26,8 \\
Elementary School & 3 & 7, \\
Junior High School & 9 & 22,0 \\
High School & 15 & 36,6 \\
Bachelor & & \\
\hline Karana & 35 & 85.4 \\
\hline Good & 5 & 12.2 \\
Moderate & 1 & 2.4 \\
Poor & & 75.6 \\
\hline Quality of Life & 31 & 19.5 \\
\hline Good & 8 & 4.9 \\
\hline Moderate & 2 &
\end{tabular}


Table 2

Correlation Annalysis of Implementation of the Tri Hita Karana with the Quality of Life of Heart Failure Patients

\begin{tabular}{|c|c|c|c|c|c|c|c|c|c|c|}
\hline \multirow[b]{3}{*}{$\begin{array}{l}\text { Implementation of } \\
\text { Tri Hita Karana }\end{array}$} & \multicolumn{8}{|c|}{ Quality of Life } & \multirow{3}{*}{$\begin{array}{c}p \\
\text { value }\end{array}$} & \multirow{3}{*}{$\begin{array}{l}\text { Coefficient } \\
\text { Correlation }\end{array}$} \\
\hline & \multicolumn{2}{|c|}{ Good } & \multicolumn{2}{|c|}{ Moderate } & \multicolumn{2}{|c|}{ Poor } & \multicolumn{2}{|c|}{ Total } & & \\
\hline & $\mathrm{N}$ & $\%$ & $\mathrm{~N}$ & $\%$ & $\mathrm{~N}$ & $\%$ & $\mathrm{~N}$ & $\%$ & & \\
\hline Good & 30 & 73,2 & 5 & 12,2 & 0 & 0,0 & 35 & 85,4 & & \\
\hline Moderate & 1 & 2,4 & 3 & 7,3 & 1 & 2,4 & 5 & 12,2 & 0,001 & 0,610 \\
\hline Poor & 0 & 0,0 & 0 & 0,0 & 1 & 2,4 & 1 & 2,4 & & \\
\hline Total & 31 & 75,6 & 8 & 19,5 & 2 & 4,9 & 41 & 100 & & \\
\hline
\end{tabular}

\section{DISCUSSION}

This study shows the results that most respondents have a good quality of life. The quality of life of patients with heart failure is influenced by various factors including sociodemographic factors, stress levels, NYHA grade classification, treatment compliance levels, self-care management, family support, and emotional intelligence [11]. Seen from table 1 , most of the respondents are still in work status. A better quality of life score in working heart failure patients is associated with research results showing that anxiety, stress, and stress can be reduced in patients who work. Work also has a positive effect on financial, physical activity, and social relationships of patients [11].

The lower the stress level, the higher the quality of life in heart failure patients, this is confirmed by one of the studies from Tatakude that there is a significant relationship between the level of depression and the quality of life of heart failure patients ( $p<0.05)$ [12]. Another study shows that the level of depression is a predictor of the quality of life for heart failure patients. Heart failure patients who were more depressed tended to experience a worse overall quality of life [13].

Apart from being able to build psychological health, the implementation of Tri Hita Karana by respondents can be seen as physical activity in the Parahyangan dimension which includes praying, meditating, and deepening religious teachings. The Pawongan dimension can be seen from how heart failure patients try to maintain good relationships with other people, while the Palemahan dimension can be measured from the efforts to protect the surrounding environment. These three dimensions indicate the physical activity carried out routinely by the respondents in this study. The readiness of a patient to do physical activity has a positive relationship to help improve one's quality of life [14].

The Tri Hita Karana concept is also in line with the nursing metaparadigm which includes nursing, human, environmental and health. In Peplau's Psychodynamic Nursing theory, it is stated that humans are living organisms in an unstable balance and the environment is implicitly defined as forces that exist outside the organism and in the 
context of culture, customs, and beliefs are obtained, whereas nursing is an interpersonal process that significantly helps humans. in achieving the degree of health [15]. Tri Hita Karana is not only a spiritual concept but also regulates the harmony of human-human relations through interpersonal processes and social interactions, as well as human relations with the environment [8]. This concept of balance will help humans improve the quality of life and achieve a degree of health.

\section{CONCLUSION}

There is a significant relationship between the implementation of Tri Hita Karana on the quality of life of heart failure patients at the Mangusada Regional Hospital in a positive direction. The better the implementation of Tri Hita Karana, the better the quality of life for patients with heart failure. The results of this study are expected to be used in providing education to patients by implementing Tri Hita Karana to improve the quality of life for patients with heart failure.

\section{REFERENCES}

[1] D. Prihatiningsih and T. Sudyasih, "Perawatan Diri Pada Pasien Gagal Jantung," J. Pendidik. Keperawatan Indones., vol. 4, no. 2, 2018.

[2] Kemenkes RI, Riset Kesehatan Dasar. Jakarta: Kementrian Republik Indonesia, 2018.

[3] D. Djamaludin, R. Tua, and D. Deria, "Hubungan Self Care Terhadap Kulitas Hidup pada Klien gagal jantung di oli Jantung RSUD Dr. H. Abdul Moeloek
Provinsi Lampung Tahun 2017," Holistik J. Kesehat., vol. 12, no. 3, pp. 178-188, 2018.

[4] M. T. D. Hasibuan, "Gambaran Kecemasan Pada Pasien Gagal Jantung Kongestif Yang Menjalani Rawat Inap Di Murni Teguh Memorial Hospital," Indones. Trust Heal. J., vol. 1, no. 1, 2018.

[5] A. N. Akhmad, "Kualitas hidup pasien Gagal Jantung Kongestif (GJK) Berdasarkan karakteristik Demografi," J. Keperawatan Soedirman, vol. 11, no. 1, p. 27, 2018.

[6] D. Utami, Fitri \& Hudiyawati, "Gambaran dukungan sosial pada pasien gagal jantung," 2019.

[7] I. Suratinoyo, J. V Rottie, and G. N. Massi, "Hubungan Tingkat Kecemasan dengan Mekanisme Koping pada pasien Gagal Jantung Kongestif di Ruangan CVBC," ejournal Keperawatan Vol., vol. 4, no. 1, 2016.

[8] I. W. Padet and I. B. W. Krishna, "Falsafah hidup dalam konsep kosmologi," Genta Hredaya, vol. 2, no. 2, pp. 37-43, 2018.

[9] I. W. Artana, "Implementasi Konsep Tri Hita Karana Pada Kualitas," Unmas Denpasar, no. 11, pp. 121-128, 2016.

[10] D. Y. Kusuma, H. Shatri, I. Alwi, and M. Abdullah, "Validity and Reliability Studies of the Indonesian Version of the Minnesota Living with Heart Failure Questionnaire (MLHFQ): Quality of Life Questionnaire for Patients with Chronic Heart Failure," Acta Med. Indones., vol. 51, no. 1, pp. 26-33, 2019. 
[11] A. Izzuddin, S. F. Dinianty, and Z. Nazaahah, "Studi Literatur: Faktorfaktor yang Mempengaruhi Kualitas Hidup Pasien Penderita Gagal Jantung di Indonesia," J. Ilmu Kedokt. dan Kesehat., vol. 7, no. 1, pp. 381-392, 2020.

[12] C. Tatukude, S. H. Rampengan, and A. L. Panda, "Hubungan tingkat depresi dan kualitas hidup pada pasien gagal jantung," J. e-Clinic (eCl), vol. 4, pp. 115121, 2016.

[13] S. L. Hwang, W. C. Liao, and T. Y. Huang,
"Predictors of quality of life in patients with heart failure," Japan J. Nurs. Sci., vol. 11, no. 4, pp. 290-298, 2014.

[14] R. Jepsen, E. Aadland, L. Robertson, M. Kristiansen, J. R. Andersen, and G. K. Natvig, "Factors and associations for physical activity in severely obese adults during a two-year lifestyle intervention," PeerJ, vol. 2014, no. 1, pp. 1-17, 2014.

[15] M. R. Alligood, Nursing theorists and theirworks, 8 th. St Louis Missouri: Mosby Elsevier., 2014. 